\title{
Information and Communication Technologies and Teacher Educators of English in Nepal
}

\author{
Prem Prasad Poudel
}

\begin{abstract}
Nepal's teacher education is witnessing a number of hurdles and the case has been deteriorating further. It is imperative to improve the existing situation with no delay. Regarding Information and Communication Technologies (ICTS), I have tried to figure out the present situation of knowledge, practice and expectations of the teacher educators of English working in both public/community and private teacher education institutions of Nepal. A survey was conducted using a questionnaire. A total of twenty-five informants fully responded to the questionnaire. It was found that they were aware of the need for including ICTs in classroom instruction but due to the resource constraints, lack of trainings and lack of readiness in the administrative systems, they have not been able to make use of ICTs in classroom instruction.
\end{abstract}

Keywords: teacher education, information and communication technology, ICTs policies

\section{Introduction}

Nepal's teacher education programme has a history of almost seven decades. Within this period, teacher education in Nepal seems as if it is continuing in the same or similar pattern. There were and are a number of challenges piled up in front of it. One of them is the case of utilization of ICTs. Since the turn of new millennium, there have been visible impacts of global expansion of Information and Communication Technologies (ICTs) almost in all parts of the countries in the world. There have been rapid transformations. Due to such inevitable happenings, the teachers, students, and teacher education institutions have faced numerous new problems, challenges and uncertainties. In the context of developing countries, ICTs are often seen as empowering tools which provide people with access to opportunities and choices that were hitherto not available (Shrestha, 2011). In the present context, there is a huge demand from the general public that there should be integration of ICTs in classroom instruction and the service providing institutions should create an ICTs friendly teaching and learning. It is an additional quality demand on teachers; and cultivating such knowledge and skills is the responsibility of teacher educators and the institutions they work in. In such changed contexts, teacher roles and responsibilities have to be redefined and accordingly the curricular changes have to be made. One of the crucial challenges for English language teachers and teacher educators (similar is the case with all other subject teacher educators) at present is the 
use of ICT in teaching learning process. Cheng (2005) writes,

In such a rapidly changing context, how teachers can be empowered and prepared to take up new roles and perform teaching effectively to meet the challenges and new expectations from education reforms is a crucial concern in policy making, reform and practice of teacher education. (p.39)

It is true that well-prepared and wellequipped teachers can help learners adjust to rapidly changing socio-economic conditions and digital technologies. We know that our societies expect our education systems to go beyond simple transmission of subject knowledge. To enable our learners to adjust to the changing needs of the labour market and everyday life, we need to facilitate them obtain new competencies, viz. digital technologies. It is mandatory now that the teacher education programmes must be prepared to cope with ICTs challenges. We have seen that throughout the world, schools expect to recruit new teachers having the ability to adopt ICTs in their teaching and learning situations. There are opportunities and challenges posed by digital technologies in delivering quality education for all. If the digital technologies can be used properly, there is a chance of profoundly improving the quality and efficiency of our education programme. Due to the paradigm shift from traditional site-bound learning to modern triplized learning (Cheng, 2001b), the quality and role of a teacher in the new century is completely different from the traditional one.

In order to address this challenge, teacher educators themselves should be able to exhibit this competency. Lee and Sparks (2013) found that teachers lack technology integration skills. Nepalese teacher education programmes also suffer from such a problem. It is high time to make Nepalese teacher education more competitive, comprehensive and as a whole qualitative on a par with the global trend. Quality education can be a reality only when there is sufficient investment in teachers. Preparing quality English teachers comes under the responsibility of teacher educators of English. A report presented by EFA Global Monitoring Report team (2015) in Oslo Summit declared to ensure that teachers and educators are empowered, adequately recruited, welltrained, professionally qualified, motivated and supported within well-resourced, efficient and effectively governed systems. So the teacher educators of English should not only think of developing pre-service teachers' knowledge of English and its pedagogy, but also the skills in using ICTs for better classroom delivery as demanded by the $21^{\text {st }}$ century socio-cultural context.

\section{Objectives}

The objectives of this survey were two-fold:

- To find out the existing knowledge and skills in ICTs of English language teacher educators in Nepal and

- To find out the needs of those teacher educators regarding the use of ICTs in the classroom

\section{Methodology}

In order to get a broader picture of the existing knowledge and skills of English language teacher educators teaching in public/community and private teacher education institutions in Nepal, a questionnaire format was adopted. A total of twenty-five teacher educators of English from ten teacher education institutions 
(both public/community and private) located in Kathmandu, Bhaktpur, Lalitpur, Kaski, Surkhet, Dadeldhura, Chitwan, and Butwal were selected purposively as the respondents. The informants whose views were sought were all involved in teaching English at Bachelor and Master levels in the constituent and affiliated campuses of Tribhuvan University. These campuses selected represent the major teacher education institutions in the valley and other regions of the country. It ruled out the possibility of clarifying face-to-face wordings of the questions and precise meaning of the responses, though I could make short interactions informally with the colleagues in my workplaces and also through telephone contacts.

\section{Results and Discussion}

There was a time when society believed that teachers were born, not trained. But today, teachers are made by continuous input through training and refresher courses. This is necessary in order to keep pace with the developments in the related areas and to work as the maximum efficiency level.

\section{ICT policies at national and institutional level}

Government of Nepal (GoN), Ministry of Education some years ago through its National Curriculum Framework included a provision of ICT as a subject and as a tool for instruction in school education (ICT Master Plan, 2013-17). In line with this, Tribhuvan University, Faculty of Education developed a separate course in ICT education. This reveals the fact that the government as well as the universities have initiated to introduce the courses in ICT; but still there is a huge gap in understanding that instead of encompassing ICT as a subject, it is more imperative to adopt it as a tool for instruction and learning. For instance, English language teacher educators are to be enabled to use ICT tools and resources in their classrooms so that they can prepare better teachers who in immediate work places can implement national policies of ICT-based teaching and learning. When inquired, a huge majority of Teacher Educators of English (TEEs) were aware of the existence of the national policies for ICT in education, however, a few of them could justify the influence of the policy in their institution and their behaviour in the class as a whole. They claimed that there had been no any professional initiative for empowering them from the institutional level even though it has been years since the ICT policies were developed.

\section{ICT knowledge and practice among TEES}

In order to transform the society to tackle with the $21^{\text {st }}$ century challenges, teachers must be more informed and empowered in the latest developments. In doing so, teacher preparation courses are to be so competitive that there is no stone unturned regarding their knowledge and skills so that they can better provide good input to the future teachers. Competency in ICT is one of the obligatory aspects on the part of their expertise. In the survey of English language teacher educators teaching in the public/ community and private teacher education institutions in the country, it was found that more than half of them were unable to handle basic computer programmes necessary for and useful in classroom delivery.

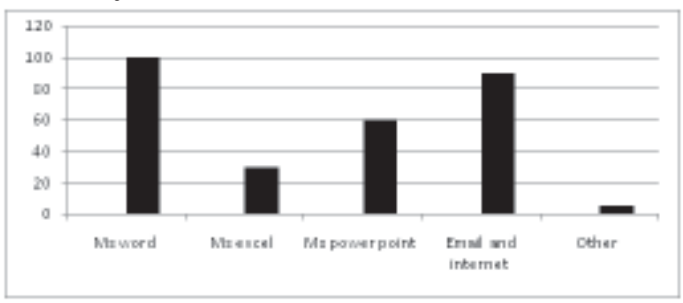

Figure 1: TEE's knowledge of computer programmes 
Figure 1 shows that all the teachers consulted for data collection had the knowledge of using Msword. Very few of them could use Ms excel well, i.e. only 30 percent of them. Similarly, 60 percent had the knowledge in power point and 90 percent of them claimed that they know how to use email and Internet. Very few, almost negligible, teachers had knowledge of other programmes such as BB Flash back, PRO 4 recorder, etc. This provides us with a picture that English language teacher educators at present need further input in using ICT comfortably.

\section{Use of computer and the Internet for classroom instruction}

Technology in general and information technology in particular is affecting the education system all over the globe in a revolutionary way. Both learners and teachers cannot be untouched by its effects. Srinivas (2004) writes that technology is affecting education in revolutionary ways and the momentum towards these changes is irreversible. TEEs have felt the need for using the Internet as one of their most feasible tools for finding out the most useful resources for necessary content and methodologies. All of them responded that there is high importance and necessity of using ICT tools for classroom instruction. There is a satisfactory situation that the teachers visit websites for the resources. On average, the TEEs surfing and using computer for classroom teaching were found in majority.

They claimed that they would accumulate the content and develop skills for using ICTs.

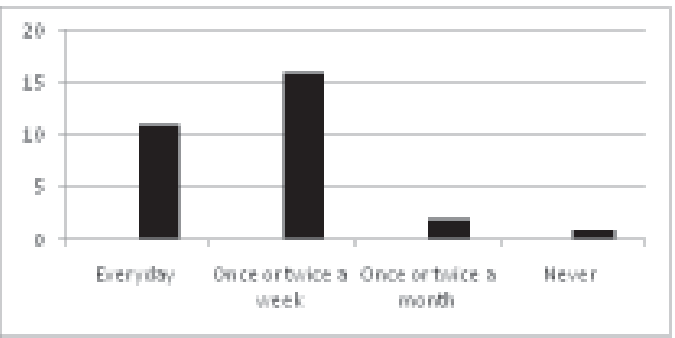

Figure 2. Frequency of internet surfing amongst TEEs

This shows that TEEs use the Internet for downloading or consulting the resources for teaching and learning. This situation is not embarrassing since Nepal's teaching profession has not been modernized yet as expected. However, it is a good signal that teacher educators have the readiness for adopting the requirement of ICT. Utilizing this existing potential of TEEs, we can make a great shift from traditional forms of teaching to modern methodologies.

\section{Trainings and professional development activities}

For the success of any institution, its human resource should be competitive, skilled, proficient, willing, and professional. To be professional, they are to be able to adopt new innovations in the respective fields. In teacher education as well, the Internet, web technologies and digital-based electronic information are exerting pressure on the traditional systems. In this survey, it was attempted to find out how often the teacher educators get opportunities while identifying training needs for using ICTs in their classrooms. It was found that they are rarely involved in the process of need analysis in using ICTs by the governmental organizations, their university and the campuses they work in. The teachers responded that they had never got training opportunities organized or sponsored by the concerned institutional and administrative system. However, it was found that they had obtained trainings (mostly basic 
computer course) through their own initiation in out-of-campus situations. On average, they had attended trainings of 515 hours. Very interestingly, they are not sure of the effect of such training in their career advancement because the institutions they work do not demand the mandatory and proper use of such knowledge and skills. One of the TEEs responded,

'I am sure that the institution I work doesn't know the level of ICT skill I have and how the students would have been benefitted from my competency in classroom delivery. It is very important in our subject that the pre-service English teachers are to be exhibited or at least familiarized with the procedures of using ICT in teaching English and the activities they can design while doing so with the resources available.'

This is a reflective image of the English language teacher education situation in Nepal. It is common to both public/ community and private institutions. Teachers have the similar plights since more than 90 percent of the classroom deliveries are made through the use of the traditional transmission and 'jug-mug' type of teaching methods.

\section{ICT obstacles, needs and expectations}

In the teacher preparation courses in Tribhuvan University and Purbanchal University of Nepal, there are a number of courses that deal with English language teaching methods; however, no space has been given to the type of course for the development of the ICT skills on the part of the teachers. There are some chapters that deal with the theoretical topics such as CALL, OHP, multimedia projector, etc. However, learning these concepts develops awareness towards ICTs but not the skills in using them. Very frequently, teachers are asked to learn new methods of teaching such as communicative language teaching, reflective teaching, TBLT, etc. but there is less discussion and concern made about greater challenges of rapidly increasing technological changes.

In the survey, they were asked about the main barriers or problems and needs for them related to the adoption of ICT-based instruction in English Language Teacher Education (ELTE). The data elicited were coded and grouped into the following major obstacles.

a. Resource constraints: It is true that, considering the situation of resources and technology, both in-service and pre-service teacher education programmes are run in crisis. There seem to be both institutional and individual concerns and problems. Some institutions want to have some or limited resources but they do not push their teaching staff to make maximum and most effective use of the available resources. On the other hand, some institutions do not have such resources at all. The majority of the institutions under the university system are under-resourced. Some of them have internet WIFI, but this is slow and irregular due to frequent power-cuts.

b. Low motivation amongst TEEs and poor collegiality: It was frequently reported that the TEEs themselves are not motivated as expected towards the learning process. They claimed that they do not participate in the rarely available ICT learning opportunities due to the administrative biasness they had been experiencing for long. Some of their colleagues are well-familiar or 
skilled in using the ICTs but due to the lack of the culture of sharing or collegiality, others have not been benefitted from those learned ones.

c. Poor access and competency in using ICTs: Many of the respondents reported that they use mobiles and their own personal devices such as laptops, PCs for surfing the Internet. When they search the valuable and most significant learning materials useful for their classroom delivery, they cannot get access to them. The access facility has not been made available to them through the libraries or administrative system of the institution they work in. The case is further miserable in students. Many students do not respond to the webbased resource sharing done by some teacher educators. From my own experience, I can strongly claim that the access and competency of the teacher educators and their students is very poor. Hence, lack of access and poor competency are the common problems for both teachers and students.

With these obstacles, TEEs have been working for long. They know and are aware of the value of ICTs as a part of their professional and personal life. They want to make changes, but they also expect some changes or provisions made in the institutions they have been working in. Some of the expectations are:

- Inclusion of ICTs as one of the core areas of English language teacher education programmes: The course developers and academic institutions should develop positive attitude towards value of ICTs in teacher education.

- $\quad$ Training packages to be developed and delivered to all the teacher educators of
English: In-service teacher education would be more effective in adopting the latest innovations in using ICT in classroom instruction.

- Management of resources in the classroom and within the premises: TEEs expect their classroom to be wellequipped with ICT resources and availability of the high speed Internet facility in the premises of the institutions where they work.

- A visionary leadership: There was a strong voice to have the leadership a good vision to reshape English language teacher education. Only a well-informed and dedicated leadership can make changes in adopting innovations and execute for the best use of the resources available.

\section{Conclusion}

Information and communication technologies have been indispensable tools for the effective teaching leaning systems. To prepare the teachers for the $21^{\text {st }}$ century, the teacher education programmes and teacher educators are to be much more competitive, competent and skillful. In order to do so, the inclusion of ICTs is a basic requirement in teacher education programmes. In the same line, through the survey, I would like to conclude that Nepalese teacher educators of English are not competent enough in using ICTs in classroom instruction. They need trainings, resources and support in order to be capable of adopting ICT-based instruction and prepare more able, competent and professional teachers of English to tackle with the $21^{\text {st }}$ century global challenges of teaching English. 


\section{References}

Ayers, W. (1993). To teach: A journey of a teacher. New York: Teachers College Press, Columbia University.

Cheng, Y. C. (2001a). Educational relevance, quality and effectiveness: Paradigm shifts. Invited keynote speech presented at the International Congress for School Effectiveness and School Improvement held in Toronto, Canada, 2001, January, with the theme 'Equity, Globalization and Change: Education for the 21st Century'.

Cheng, Y. C. (2001b). New education and new teacher education: A paradigm shift for the future. In Y. C. Cheng, K. W. Chow, \& K. T. Tsui (Eds.). New teacher education for the future: International perspectives (pp. 33-88). Hong Kong \&The Netherlands: Hong Kong Institute of Education and Kluwer Academic Publishers.

Cheng, Y. C. (2005). Three waves of teacher education and development: Paradigm shift in applying ICT. In Mohamed Chaib \& Ann-Katrin Svensson (Eds). ICT in Teacher Education: Challenging Prospects. Jonkoping : Jonkoping University Press.
EFA Global Monitoring Report Team (2015). Investing in teachers is investing in learning: A prerequisite for a transformative power of education. A background paper presented for the Oslo Summit on Education for Development. Oslo: Author.

Lee, J.C \& Sparks, P. (2013). Three hurdles in technology integration: A case study of technology integration in Bungamati. Journal of NELTA, 18 (1-2), 105-114.

Ministry of Education (2013). Information and communication technology in education master plan 2013-17. Kathmandu: Author.

Shrestha, P. (2011). The potential of mobile technologies for (English) language learning in Nepal. Journal of NELTA, 16 (1-2), 107-113.

Srinivas, K. (2004). Globalization and challenges for education. New Delhi: Shipra Publications.

\section{Author's bio}

Prem Prasad Poudel, M. Ed. and M. Phil, is a faculty at Tribhuvan University, Nepal. He has been carrying out research studies in English Language Teaching and Teacher Education and has published in various national and international journals. He is a teacher trainer, textbook writer, translator and Master Trainer of Critical Thinking Methodology. 